\author{
Драган Бисенић
}

\title{
Идејне борбе у раној револуционарној Кини и совјетски утицај на бољшевизацију кинеске Комунистичке партије
}

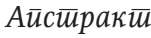

Комунистичка идеја у Кини њихала се између национализма и интернационализма, пролетаријата и сељаштва, урбанизације и заосталих руралних предела и маса. У овим супротностима израстале су и водеће личности које су, зависно од властитог порекла, друштвеног статуса и контаката са светом, градили свој поглед на могућност пролетерске револуције у Кини. У идејном развоју КП Кине можемо да уочимо три периода до 1935. године, када долази до промене односа снага у корист Мао Цедунга који ће постати историјски вођа кинеских комуниста. Први период обухвата време од појаве првих комунистичких организација у Кини, које су створене уз помоћ инструктора Коминтерне, до почетка сарадње са Куоминтангом. Други период је време од раскида са Куоминтангом 1927. до избора тзв. „бољшевичког руководства” 1931. Трећи период је „бољшевичко-совјетски” период деловања КП Кине, који траје од 1931. до 1935, и одржавања Зуниј конференције, када долази до раскида са овом линијом и после које почиње успон Мао Цедунга.

Кљуине речи:

идејне борбе, троцкизам, Мао Цедунг, К. А. Стојановић, Северна експедиција, група „28 бољшевика”, Дуги марш

Кинески песник Ван Сју Бо написао је следеће стихове о КП Кине: „Комунисти су нам отворили Пут победе, Без комуниста нема Кине. Комуниста воли народ свој Комуниста неустрашиво иде у бој. Воља комуниста 
живот нам је дала. Пут комуниста прав је као стрела". Већ из првог стиха јасна је снажна повезаност комунизма и Кине. Каже се „без комуниста нема Кине". Како је могуће да је Небеско царство, које је трајало хиљадама година, постало толико повезано и идентификовано са једном идеологијом која је земљи омогућила невероватни просперитет и очување националног достојанства, чак и када је та идеологија напуштена у већем делу света у ком је постојала? Одговор би морао да буде да је она у кинеском случају нешто више од пуког идеолошког апарата. У овом излагању настојаћу да укажем шта би могао да буде одговор на примеру раних идејних борби у КП Кине.

Како је било могућно да се комунизам развије у друштву које практично није имало никаквог додира с комунистичком идеологијом, осим студената који су га упознали у Европи и у Русији, а затим да се успостави као доминантна идеја у неразвијеном сељачком и полуфеудалном друштву?

Прве деценије 20. века биле су доба великог превирања у Кини. Земља је све дубље падала под власт странаца, тако да је 1911. нестало династије и Небеског царства. Али, био је то почетак великих нереда, несигурности и нестабилности у Кини, којом почињу да владају три војне клике које су тако поделиле и земљу, са мноштвом локалних банди које су пљачкале и терорисале становништво.

Полувековни премијер Ли Хунгјанг водио је политику која је очувала достојанство и суверенитет, иако смањен, поносног становништва (Кисинџер, 2020, стр. 87). У свом писму царици нешто пре своје смрти 1901. закључио је да Кина није у стању да води рат. „Гледајући на то питање као основно питање интегритета нашег царства, ко би био тако будаласт, а да испали пројектил на пацова у близини непроцењивог комада порцелана", писао је Ли (Bland, 2015, р. 306).

Комунистичка идеја у Кини њихала се између национализма и интернационализма, пролетаријата и сељаштва, урбанизације и заосталих руралних предела и маса. У овим супротностима израстале су и водеће личности које су, зависно од властитог порекла, друштвеног статуса и контаката са светом, градиле свој поглед на могућност пролетерске револуције у Кини.

Најважније теме ових спорова тицале су се начина и метода борбе, будући да у Кини није било значајног радништва. Од 400 милиона становника било је само два милиона раднике, дакле, мање од једног процента. Коминтерна је стога стајала на становишту да је потребна прво национално-демократска борба која је укључивала сарадњу са Куоминтангом да би се створили услови за социјалистичку револуцију. Друго питање било је ко је субјект револуције, ако нема радништва? Може ли 
то да буде сељаштво, као што је то сматрао Мао Цедунг, који је због тога добио и погрдан надимак „сељачког револуционара”?

Иако се све дешавало у земљи која је била марксистичка периферија, ово нису била нимало споредна питања. Управо ће она довести до првог великог расцепа у међународном комунистичком покрету после Октобарске револуције јер ће „кинеско питање” и кинеска револуција постати врхунац сукоба између Троцког и Стаљина 1927. и 1928. године, када је Троцки дефинитивно искључен из редова совјетских комуниста.

Аустријски надвојвода и један од ретких личних сведока целог 20. века, Ото фон Хаббсбург, у разговору који смо водили 2009, имао је јединствено објашњење појаве, трајања и успеха комунизма у Кини. После Боксерског рата склопљен је мир између Кине и европских држава. Посебан уговор је склопљен између Немачке и Кине, јер је немачки амбасадор убијен у рату. Немачки цар Виљем II у уговору је тражио једну ствар, коју нико други није. Он је тражио да принц дође у Берлин и да се поклони немачком цару. У то време у Кини такво поклањање резервисано је искључиво за цара Кине, па је то што су Немци тражили за Кинезе значило губљење образа. Дан када се принц наклонио испред немачког цара - то је био дан када је створен комунизам у Кини. „Јер њихов комунизам није комунизам, већ представља тренутак када је све племство Кине схватило колико је важно сачувати образ. То објашњава и Чоу Енлај, који је био велики мислилац и био је веома утицајан човек међу великим породицама. Зато ћете у кинеском комунизму наћи много људи који следе велику традицију кинеског племства. Они су свуда", објаснио је Хаббсбург. ${ }^{1}$

„Понижење - то је кључна реч. Након свих векова наше цивилизације, након свега што смо дали људској раси, од Запада смо добили само једно: понижење", рекао је Чу Енлај на тераси египатског председника Насера, када је у зиму 1961. био у Каиру на чувеном тројном сусрету Насер - Нехру - Чу Енлај.

О томе колико је осећање националног поноса било важније од класне структуре и бољшевичких догми за усвајање и примену кинеског схватања марксизма говори и појава и деловање „Покрета 4. мај”. Јапан је у време Првог светског рата поставио „21 захтев” које је председник тадашње пекиншке Владе Јуан Шикај усвојио како би се уз помоћ Јапанаца прогласио за цара. Послератна Версајска конференција није удовољила кинеском захтеву за повлачењем страних трупа из Кине

Интервју аутора са Отом фон Хабсбургом (1912-2011) вођен 2009. Ото фон Хабсбург био је последњи аустроугарски престолонаследник од 1916. до распада империје у априлу 1919. Хабсбург је водио живу дипломатску и међународну активност и био је посланик Европског парламента у више мандата. 
и одобрила је јапанску окупацију кинеских територија. Овакав резултат Париске мировне конференције огорчио је кинески народ па је 4. маја 1919. преко 5.000 студената Пекиншког универзитета изашло на барикаде, а талас солидарности са студентима захватио је целу земљу.

После Октобарске револуције Русија је за кинеске комунисте постајала светионик, као што је то Француска била 1870. за енглеске радикале. Марксизам се ширио постепено, али успех бољшевика снажно је заинтригирао кинеске патриоте и интелектуалце. Марксизам је дошао као идеја која говори о томе како се историја креће напред. Многи су почетком двадесетих година прихватали марксизам јер су сматрали да он омогућава Кини револуцију попут оне у Русији, чиме би се спасила нација, искоренила назадност, ослободила енергија преплашеног народа, а хероји „Покрета 4. маја” добили би истински друштвени контекст.

Била је то атмосфера у којој су сазревале марксистичке револуционарне идеје. Комунистичка интернационала је плодно тле и савезнике за деловање налазила у првом реду у „антиверсајским срединама” које су желеле ревизију овог мировног уговора. То су биле Русија, односно СССР, Немачка и Кина.

У идејном развоју КП Кине можемо да уочимо три периода до 1935. године, када долази до промене односа снага у корист Мао Цедунга, који ће постати историјски вођа кинеских комуниста.

Први период обухвата време од појаве првих комунистичких организација у Кини, које су створене уз помоћ инструктора Коминтерне, до почетка сарадње са Куоминтангом.

Други период је време од раскида са Куоминтангом, 1927, до избора тзв. „бољшевичког руководства” 1931.

Трећи период је „бољшевичко-совјетски” период деловања КП Кине, који траје од 1931. до 1935, и одржавања Зуниј конференције, када долази до раскида са овом линијом и после које почиње успон Мао Цедунга.

\section{ПРВА ФАЗА: РАЗВОЈ МАРКСИСТИЧКЕ ИДЕЈЕ И ФОРМИРАЬЕ КП КИНЕ}

Ментално семе марксизма појавило се у часопису „Нова младост” који се борио за ослобођење. Марксизам, као доктрина Маркса, Енгелса и Лењина појавила се тек као трећи стадијум у кинеском развоју. На идеолошком плану, најважнију улогу у ширењу марксизма имала је појава превода Марксовог „Манифеста комунистичке партије”. Први део Манифеста се на кинеском појавио у новембру 1919. године, иако су поје- 
дини делови Манифеста били преведени 1909. и тада је то било најзначајније марксистичко дело које је преведено. „Капитал” је преведен много касније.

Акутна унутрашња криза у земљи и исход Вашингтонске конференције изазвали су буру огорчења које се пренело на студентски „Покрет 4. мај" 1919, а прихватили су га широки слојеви кинеске омладине и интелектуалаца. Још раније је почео да се развија „Покрет за нову културу”, који је резултирао увођењем говорног језика „баихуа” у политичко новинарство и књижевност, што је милионима Кинеза омогућило да се описмене. „Покрет за нову културу” и „Покрет 4. мај 1919” привукли су у револуционарну борбу образоване слојеве кинеске омладине и допринели консолидацији младе кинеске радничке класе, која се манифестовала у њеним првим организованим наступима, укључујући штрајкове.

Почетак комунистичког деловања Коминтерне у Кини повезује се са Другим конгресом Коминтерне (1920), али први контакти руских комуниста са представницима револуционарне интелигенције Кине започели су одмах након формирања III комунистичке интернационале, почетком марта 1919 (Сотникова, 2011, стр. 126).

Револуционарне народноослободилачке идеје засноване на доктринама позајмљеним из Европе, које су се показале у пуној снази већ на почетку 20. века, у ери „буђења Азије”, допринеле су стварању стихијних омладинских кружока за проучавање најрадикалније и најдетаљније разрађене доктрине револуционарног спасења - марксизма. Међу њиховим учесницима могле су се срести присталице анархизма, „легалног марксизма" и националисти, и уопште случајни сапутници.

Члан Харбинске илегалне организације РКП (б) Н. Г. Буртман се у то време у Пекингу састао са професором економије и директором библиотеке Универзитета у Пекингу, Лиом Дажаом, који је први у Кини скренуо пажњу на значај бољшевичког искуства и почео интензивно да пропагира руски комунизам (Клик, 1981, стр. 203-208). Буртман је у јесен 1919. оценио Лиа Дажаоа „одличним марксистом”.

У мају 1920. талентовани публициста и агитатор, који је уживао огромно поштовање патриотске интелигенције, декан Високе школе за хуманистичке науке, професор Пекиншког универзитета Чен Дуксиу $^{2}$, око кога су груписани млади марксисти, уз активно учешће

Чен Дуксиу (Chen Duxiu, 1879-1942), кинески револуционарни социјалиста, филозоф и писац, у 1921. саоснивач кинеске Комунистичке партије, заједно са Лиом Дажаом, први генерални секретар КП Кине од 1921. до 1927. Био је водећа личност Ксинхај револуције, којом је збачена династија Чинг, и Покрета 4. мај за научни и демократски развој у раној Републици Кини. Избачен је 1929. из Комунистичке партије, а био је и лидер малог троцкистичког покрета у Кини. 
Г. Н. Војтинског, организовао је Револуционарни биро у Шангају, који се састојао од пет људи (осим Г. Н. Војтинског, још четири кинеска револуционара, укључујући Лиа Дажаоа) (Хэнъюй, Титаренко, 1994, стр. 51).

Први конгрес КП Кине одржан је илегално 23. и 31. јула 1921. године, у којем је учествовало 12 делегата који су представљали 7 марксистичких кругова (чинило их је 53 људи). Конгресу су присуствовали представник Коминтерне Г. Маринг (Х. Сневлит) и представник Далекоисточног секретаријата Извршног комитета Коминтерне, Никољски (В. А. Најман). Делегати су изабрали Централни биро на челу са Ченом Дуксиуијем. Неспремност кинеских комуниста да сарађују с другим партијама демократске оријентације, која се манифестовала у одлукама конгреса, била је у супротности са принципима Коминтерне и захтевала је значајне напоре њених представника да промене став руководства КП Кине по овом питању.

Партија је ишла „урбаним” путем. Генерални секретар је био професор Чен Дуксиу, који је био довољно марксиста да је видео мало наде у слеђењу „руралног” пута. Они који су се вратили са студија у Европи, попут Лија и Лиуа, нису сматрали да би пролетерска револуција у Азији могла да се разликује од Европе.

Занимљиво је да се међу Коминтерниним делегатима који су припремали оснивачки конгрес КП Кине налазила и личност која по презимену асоцира да је из наших корена, односно личности која је користила псеудоним наших корена, што је била тада редовна пракса Коминтерне и комунистичких организација - К. А. Стојановић. Ипак, овде је реч само о псеудониму који је користио ванредни комесар ВЦИК, Константин Алексејевич Мјачин. Мјачин је познат и по свом другом псеудониму, Василиј Васиљевич Јаковљев. ${ }^{3}$ Вероватно због своје умешаности у егзекуцију царске породице Романов, узео је псеудоним током свог деловања у Кини, али је непознато како је дошао до српског презимена „Стојановић” (Авдонин, 1995, стр. 21-26).

„К. А. Стојановић” је имао велику улогу у развоју КП Кине. Када је Коминтерна почетком 1920. успоставила непосредне контакте са Суном Јатсеном, учињено је то преко Војтиновског, Маринга и К. Н. Соколова - Стахова. Пошто су први сусрети били позитивни, одлучено је да се успоставе стални канали за размену информација. Због тога је у августу 1920. као дописник телеграфских агенција ДАЛТА (Далекоисточна телеграфска агенција) и РОСТА, које су званично отворене 1921, упућен „К. А. Стојановић”. Агенције су упознавале Совјете са положајем у Јужној

Авдонин, А. Н., 1995, „В жерновах революции”, Екатеринбург, стр. 21-26. 
Кини и снабдевали информацијама Суна Јатсена, Куоминтанг и јужнокинеску штампу с догађајима у Русији (Усов, 2002, стр. 207).

Представник Омладинске комунистичке интернационале и Далекоисточног бироа Коминтерне, С. А. Далин, био је једини који је оставио своја сећања на сусрет са „Стојановићем” 22. априла 1920. године. „Отишао је најпре у Дуншан, где су живели Европљани 'друге врсте'. Ту је живео дописник ДАЛТА Стојановић. Стојановић, као представник непризнате државе, живео је с породицом у Дуншану. Високог раста, с брдом, пријатан, увек спреман да помогне, оставио је на мене веома добар утисак... Његов једини сарадник у агенцији био је Вијетнамац из француске Индокине. Говорио је француски, знао кинески и политички живот Јужне Кине. Од Стојановића сам добио прве информације о стању на југу, којима сам био изненађен. У веома мрачним цртама описан је Сун Јатсен и његова влада. Према Стојановићевим речима, оно је спроводило политику непријатељску према радничкој класи. Сун Јатсенове саборце оцењивао је као милитаристе америчке оријентације. Његове симпатије биле су на страни Чена Цунмина, генерала који је управљао покрајином Гуандун, који се ослањао на Енглеску, који је, наводно, подржавао раднички покрет и био близак с кантонском организацијом Комунистичке партије... Потом је Стојановић променио своје гледиште и радио са мном... Његова позиција изражавала је нечије погледе. Чије тачно, ја још нисам знао" (Усов, 2002, стр. 207).

"Стојановић” је активно деловао у ширењу комунистичких група и ћелија у Кини. Тако је, заједно са М. Абрамсоном, основао пекиншку комунистичку групу у лето 1920, која је коначно организационо створена у октобру исте године. У групи је, поред четворице марксиста које је предводио Ли Дажао, било и пет анархиста (Дамье, Лиманов, 2020, стр. 239). Ли Дажао је подржао уступке и укључивање анархиста у кружок, али га други марксисти нису у томе подржали, па су у новембру анархисти напустили групу, пошто се нису сложили са укључивањем концепта „диктатуре пролетаријата" у Привремени програм рада групе.

Следећа важна комунистичка група образована је у Ганџоу. Група је створена у септембру-октобру 1920. У групу је ушло и 7 анархиста. Кружок је одржавао састанке на којима је расправљано о социјалистичкој литератури и историји радничког покрета. Познати кинески анархиста Хуан Линшуан је још 1919. написао чланак под насловом „Критика марксизма" (Ван ден Вен, 1991, стр. 65). Сарадња марксиста и анархиста није дуго трајала, само до јануара 1921, када су и овде анархисти одбили да прихвате политику „диктатуре пролетаријата" (Ван ден Вен, 1991, стр. 65). 
Сарадња бољшевика и анархиста трајала је још неко време. Вођа комуниста Чен Дуксиу доказивао је Хуану Линшуану да се и бољшевици и анархисти боре за преображај друштва и због тога је потребно да делују заједно, а не да се супротстављају једни другима. У различитим регионима земље, тактика „анархисти и бољшевици иду руку под руку” одржавала се до 1923. године, када је дошло до раскида. Осим „диктатуре пролетаријата”, анархистима није био прихватљив ни концепт „класне борбе", а одбацивали су НЕП у Русији и привлачење приватног капитала као заверу бољшевика и светског капитала против народа (Дамье, Лиманов, 2020, стр. 254). Оштру критику анархиста изазвала је бољшевичка пракса обједињавања радника и радничких организација под својим вођством (Дамье, Лиманов, 2020, стр. 255).

У то време Мао Цедунг је радио као наставник. Покренуо је вечерњу школу за младиће са села испод 18 година који су желели да уче аритметику и кинески језик, али то је било место где је пропагирао своја марксистичка гледишта. Објављивали су мали часопис под именом „Ново доба" и у њему је Мао објавио своја прва два чланка која се приближавају марксистичким погледима: „Против идеализма” и „Марксизам и Кина”. Пре тога, Мао је био близак „хунанској политичкој групи” која је желела независну хунанску државу (Вавилов, 2021, стр. 246-250).

Мао је прво био педагог, а онда идеолог. Он се дивио оснивачу модерне Кине, Ћин Шихуангу, и сматрао да је Кини потребна „комбинација Марксових и Ћин Шихуангових метода" (Кисинџер, 2020, стр. 94). Уместо испита за упис студентима су постављана питања: „Изрази своју критику друштва” и „Представи своју животну филозофију”. Многи комунистички активисти у Хунану потекли су из ових редова. Мао је предавао рану историју Кине, сматрајући да ће она да пробуди код полазника осећање патриотизма (Terril, P. 1980, стр. 60).

Први конгрес КП Кине у Шангају је у једном смислу утицао на Маоа, јер је почео више пажње да поклања синдикатима. Из Шангаја је дошао с две функције - био је покрајински секретар КПК и секретар Радничког секретаријата, који је био новорођенче пројекта КП Кине. Анујан је постао прво бојно поље. То је био скроман град у источном Хунану с великим рудником угља који је отворен 1898. на иницијативу Немачке и Јапана, па је тако постао центар очекивања будуће кинеске индустријске револуције. Мао је између 1921-1923. посетио четири пута овај град, где се упознавао са условима живота и рада 6.000 рудара, који су проводили по 15 сати у руднику. У околини су постојале 24 хришћанске цркве и само једна амбуланта. Мао је основао ћелију Комунистичке партије, Раднички клуб и неизбежну вечерњу школу. 
Како би лакше агитовао међу радницима, Мао је креирао властити начин комуницирања. Показао је „ТТ” који је један део речи „рад”, односно „радник” при чему је објаснио да је горња црта небо, доња земља, а црта између представља раднике. Радници стоје на земљи, али могу да достигну небо, било је значење Маове симболике.

Син земљопоседника који је говорио енглески, Жанг Гуотао, Ли Лисан, који се вратио из Русије, и Лиу Шаочи, који се вратио из Француске, придавали су важност и значај синдикатима, али Мао, који, рецимо, никада није радио као рудар у руднику, није имао страсти, ни разумевања за такву политику, нити је био у Европи где се развила визија светске револуције преко побуне пролетаријата. Мао се питао где се визија Кине налази у раду Коминтерне?

Пролетаријат је чинио мање од једног процента кинеског становништва, а комунизам је углавном био идеја интелектуалаца. Кина је имала 2 милиона индустријских радника и 400 милиона становника. Многи синдикални активисти нису ни знали шта значи „Ма - ке - се зхуу" (марксизам) (Ross, 1980, стр. 65).

\section{СОВЈЕТСКИ САВЕЗ ИЗМЕБУ КУОМИНТАНГА И КОМУНИСТА}

Након стварања Кинеске комунистичке партије (КПК), јула 1921, и организационе регистрације Националне партије Кине (Куоминтанга), 1919, током скоро три деценије трајао је сукоб између ове две странке, на које је Совјетски Савез непрекидно имао огроман утицај.

Го Јан сматра да се овај утицај манифестовао првенствено у промоцији сарадње Кинеске комунистичке партије са Куоминтангом и пружањем подршке и помоћи обема странама у постизању равнотеже у њиховим односима ради решавања националних проблема (Ян, 2018, стр. $30)$. То није само ојачалу њихову снагу и унутарпартијски развој, него и ефективно допринело процесу кинеске револуције. Стога је утицај Совјетског Савеза на КП Кине имао за циљ прихватање компромисне политике према Куоминтангу да би се одржале могућности за сарадњу.

Други конгрес КП Кине одржан је 1922. у Шангају. Док је Први конгрес био секташки, Други конгрес је био скројен према делегату Коминтерне, Холанђанину Марингу, који је покушао и успео да измени линију са претходног конгреса. ${ }^{4}$ У децембру 1921. Маринг (Сневлит) је посетио

Hendricus Josephus Franciscus Marie Sneevliet (1883-1942), познат као Хенк Сневлит, или под псеудонимом „Маринг”, био је холандски комуниста, који је био 
Сун Јатсена на југу Кине и препоручио Коминтерни савез између КП Кине и Куоминтанга. Након њега је Михаил Бородин на Стаљинов предлог именован за сталног представника СССР-а у јужној Кини. ${ }^{5}$

Сун је продубио односе Куоминтанга са КП Кине разговорима са совјетским дипломатом Адолфом Јофеом ${ }^{6}$, који су се завршили заједничком изјавом о потреби националног јединства (Фенбу, 2008, стр. 190). У саопштењу са сусрета Сун Јатсен - Јофе, од 26. јануара 1923, који је, почев од прве објаве Коминикеа у новинама Правда и Известија 1923. и до средине седамдесетих, у принципу, био прећутан у совјетској литератури. Речено је: „Др Сун Јатсен верује да у овом тренутку комунистички систем, па чак ни совјетски систем, не може бити уведен у Кину, јер не постоје услови неопходни за успешно успостављање комунизма или совјетизма. Ову тачку гледишта у потпуности дели опуномоћеник РСФСР ..." (Усов, 2002, стр. 216).

активан у Холандији и холандској Источној Индији. Као функционер Комунистичке интернационале, руководио је формирањем Комунистичке партије Кине 1921. У Низоземској је био оснивач, председник и једини представник Револуционарне социјалистичке (радничке) партије, РСП/РСАП. Учествовао је у отпору комуниста против нацистичке окупације Холандије током Другог светског рата, због чега су га Немци погубили у априлу 1942.

5 Михаило Маркович Грузенберг, познат као Михаил Бородин (1884-1951), био је бољшевички револуционар и агент Коминтерне. Био је саветник Суна Јатсена и Куоминтанга током 1929.

Живео је у Америци до победе Октобарске револуције, када се вратио и био на различитим положајима у совјетској власти. Од 1919. био је агент Коминтерне који је путовао у различите земље да би ширио бољшевичке револуционарне циљеве. Њега је 1923. Лењин одабрао да води мисију Коминтерне у Кини, где је био задужен да саветује Суна Јатсена и Куоминтанг. После смрти Суна Јатсена, Бородин је помогао у планирању Северне експедиције, Northern Expedition, и постао је важна подршка левичарској влади Куоминтанга у Вухану.

После чистки комуниста из Куоминтанга, вратио се 1927. у Совјетски Савез, где je основао "News" новине на енглеском. Током Другог светског рата био је главни уредник Совјетског информативног бироа. Ухапшен је крајем 1940. и затворен. Умро је у затвору 1951, а рехабилитован је 1964. године.

6 Adolph Abramovich Joffe, руски Адо́льф Абра́мович Ио́ффе, (1883-1928), био је руски револуционар, бољшевички политичар и совјетски дипломата. Био је шеф совјетске делегације за мировне преговоре с Немачком у Брест Литовску од 30. новембра 1917. до јануара 1918. Био је совјетски амбасадор у Кини, а затим је преговарао у решавању совјетских отворених питања с Јапаном. Након што је тешко оболео вратио се у Москву, али истовремено је био верни присталица Троцког. Након што је Троцки 12. новембра 1927. искључен из партије, Јофе је извршио самоубиство, остављајући опроштајно писмо за Троцког. Говор који је Троцки држао на Јофеовој сахрани био је његов последњи јавни говор у Совјетском Савезу. 
Комунистичка партија и националисти су се удружили. Чланови Партије ће се придружити Националистичкој партији (Куоминтангу) као појединци, а Комунистичка партија ће и даље постојати као одвојена организација. Међутим, организационо вођство у „националној револуцији" ће бити у рукама Куоминтанга.

Мао није присуствовао Другом конгресу, који је одржан 1922. у Шангају, иако је већ био у граду. Мао је рекао да је „заборавио место где се одржава, а није било ниједног друга у околини како би сазнао", у шта је веома тешко поверовати.

Сарадња КП Кине и Коуминтанга била је најконтроверзнији део политике Коминтерне која је инсистирала да се ова сарадња настави иако су се томе противили многи водећи кинески комунисти, укључујући Маоа Цедунга. У таквим условима замишљена је операција уједињења Кине, названа „Северна експедиција”. „Северна експедиција” била је војни план Националне револуционарне армије против пекиншке владе и регионалних господара у 1926. Циљ акције било је поновно уједињење Кине, која је постала издељена после револуције 1911. године.

На Стаљинову сугестију, Бородин се сагласио да се настави помоћ Куоминтангу и да се подржи „Северна експедиција”, која је почела у јулу 1926. На конференцији Коминтерне 1926. Стаљин је објаснио наставак подршке Куоминтангу, рекавши да би „напуштање Куоминтанга од стране комуниста била најсмртоносније грешка", наглашавајући да Комунистичка партије Кине треба да ради кроз нову владу, стварајући мост између државе и сељака.

Мао Цедунг се већ 1925. године разилази са званичном линијом Комунистичке партије о сељачком питању. Ова размимоилажења посебно су дошла до изражаја након објављивања његовог рада „Извештај о испитивању сељачког покрета у Хунану". Размимоилажења су кулминирала када је Мао у новоослобођеним крајевима почео да спроводи у пракси своја схватања о сељачком питању.

„Северна експедиција” постала је тачка размимоилажења између Стаљина и Троцког. Стаљин је у бројним приликама охрабривао Комунистичку партију да сарађује с Куоминтангом, пошто је сматрао да је Куоминтанг способнији да изврши кинеску револуцију. Троцки је био против сарадње с Куоминтангом, јер је веровао да је она противна концепту пролетерске револуције. Коминтерна је одобрила Стаљинову одлуку да финансијски подржи Куоминтанг (Taylor, 2009, p. 57).

Од 1925. постепено јачају антикомунистичке тенденције међу руководством Куоминтанга. Совјетско руководство није благовремено довољно узело у обзир промене које су се догодиле, а које су временом стварале потешкоће у развоју Кинеске комунистичке партије 
(1926-1927), што је на крају довело до прекида дипломатских односа између СССР-а и владе Куоминтанга.

Против раста левичарског утицаја у новембру 1925. изјаснила се група антикомуниста, позната као „Западно брдо”, која се састала у близини Пекинга. Ово је била фракција Кинеске националистичке партије, активна током 1920. После састанка, група је објавила саопштење у коме је тражила прекид односа с Бородином и избацивање комуниста из партије. Овај захтев није имао учинка, јер је Чанк Кајшек написао писмо у ком је бранио Бородина, комунисте и односе Куоминтанга са Совјетским Савезом (Wilbur, 1983, p. 557).

Под тим условима, крајем маја 1927. године уследило је тајно Стаљиново наређење, који је био врло незадовољан што није успео да употреби Чанга Кај Шека, а затим га одбацио као „исцеђени лимун” (Стаљинов израз) тако да Комунистичка партија прекине сарадњу са Куоминтангом и његовом владом, започела конфискацију земље и формирање независне радничко-сељачке војске. Тајно упутство пало је у руке левичара Куоминтанга предвођених Вангом Џивејем. Као резултат, комунисти су избачени из владе у Ханкову и започела су њихова хапшења. Бородин и његова група су опозвани у СССР.

У септембру се неколико група Куоминтанга удружило у новој влади коју је у Нањингу формирао Чанг Кај Шек. Постао је шеф Централног извршног комитета Куоминтанга и врховни командант. Покренута је операција против Пекинга, коју је у својим рукама држао Чанг Зуолин, вођа северне и централне групе милитариста. Заузет је Пекинг, совјетске саветнике заменили су немачки официри. Започело је постепено помирење Куоминтанга са западним силама. Покушај комунистичког пуча у Кантону децембра 1927. године и стварање савета у том граду пропали су и завршили се новим крвопролићем.

\section{ДРУГА ФАЗА: НЕУСПЕХ „СЕВЕРНЕ ЕКСПЕДИЦИЈЕ” И СТВАРАҢЕ УСЛОВА ЗА ПРЕОКРЕТ (1927-1931)}

Чен Дуксијово руковођење партијом окончано је средином 1927. Његови наследници били су млађи - Ку Киубаи у другој половини 1927. године и Ли Лисан од лета 1928. до лета 1930, а онда Међународна фракција (или 28 бољшевика) од јануара 1931. до јануара 1935.

Ли Лисан је био један од првих кинеских комуниста који се вратио из Париза и учествовао на оснивачком конгресу КП Кине. 
Коминтерна је оптуживала руководство за „десничарење” и уопште је сматрала овај период полутроцкистичким, оптужујући често руководство КП Кине да се није ослободило троцкистичког наслеђа.

У фебруару 1928. године Коминтерна је окривила Комунистичку партију Кине за сопствене грешке у кинеском питању, тачније за неуспехе стаљинистичког курса, оптужујући своје руководство за „десничарски опортунизам". Генерални секретар странке Чен Дуксију смењен je са функције. Од Комунистичке партије затражено је да започне са стварањем „совјетских база”.

Троцки и други опозиционари критиковали су ток Стаљина и стаљинистичко руководство Коминтерне многим прецизним и суптилним запажањима. У бројним наступима из септембра и октобра 1927. Троцки и Зиновјев траже уклањање Стаљина и Бухарина. „Неопходно је одлучно исправљање наше линије у национално-револуционарним покретима, пре свега у Кини, ликвидација линије Мартинова, Стаљина и Бухарина и повратак линији Лењина и одлукама II и IV конгреса Коминтерне. Иначе, ми ћемо од покретача да постанемо кочница национално-револуционарних покрета и неизбежно ћемо да изгубимо симпатије радника и сељака на Истоку", писао је Троцки у септембру 1927. Ставове Троцког у неким писмима подржавали су и познати југословенски комунисти, браћа Гргур, Војислав и Радомир Вујовић.

Стаљинова стратегија, која није дозвољавала наоружавање радника и сељака и охрабривала сарадњу са буржоазијом, сматрала се рањивом после неуспеха Уједињеног фронта. Његов неуспех искристалисао је његов заокрет од међународне револуције ка „социјализму у једној земљи” (Jacobs, 1981, p. 302). Стаљин више никада није веровао Комунистичкој партији Кине, које је касније звао „маргаринским комунистима” који су одступили од марксистичког учења, опредељујући се за сељачку, а не радничку револуцију (Brandt, 1958, pp. 174-175).

После неуспеха револуције 1925-1927, амерички новинар Едвард Сноу посетио је 1936. ослобођене кинеске провинције у Шенсију и при том интервјуисао Мао Цедунга. ${ }^{7}$ На питање кога сматра одговорним за пораз револуције 1925-1927. Мао је одговорио да је то тадашњи генерални секретар КП Кине, Чен Цу, веома одговоран за неуспех револу-

Edgar Parks Snow (1905-1972), амерички новинар који је познат по својим текстовима и књигама о комунизму у Кини и кинеској комунистичкој револуцији. Био је први западни новинар који је представио историју кинеске Комунистичке партије после Дугог марша, а био је и први западни новинар који је интервјуисао њене лидере, укључујући Мао Цедунга. Он је најпознатији по својој књизи „Црвена звезда изнад Кине" (1937), историји кинеског комунистичког покрета, од оснивања до касних 1930-их. 
ције $^{8}$ и да је његов „колебљиви опортунизам лишио партију одлучног руководства и властите линије у тренутку када је даљи компромис јасно означавао катастрофу" (Орешчанин и Павловић, 1960, стр. 48).

После Чена, најодговорнији био је главни руски саветник Бородин. Мао је објаснио да је Бородин сасвим изменио свој став, изјашњавајући се 1926. за радикалну поделу земље, док се већ у 1927. одлучно томе супротстављао, без икакве логичне основе за своје колебање. „Бородин је стајао управо мало удесно од Чен Цуа”, рекао је Мао, „и био спреман да ради било шта да би задовољио буржоазију, па и по цену разоружања радника, што је на крају и наредио" (Snow, 1937, p. 161).

Индијски делегат у Коминтерни, Рој, био је нешто улево од обојице, Чена и Бородина, али је само био. „Рој је могао да говори”, према Маовим речима, „и говорио је исувише, али није предложио никакав метод реализације”. Мао мисли да је, објективно, „Рој био будала, Бородин сметња, а Чен несвесни издајник" (Snow, 1937, p. 161).

„Чена су у ствари плашили радници, а највише наоружани сељаци. Нашавши се лице у лице са оружаним устанком потпуно се изгубио. Више није могао јасно да види шта се дешава. Његови ситнобуржоаски инстинкти одвели су га у панику и пораз", рекао је Мао у интервјуу Едгару Сноу (Snow, 1937, p. 161).

\section{ТРЕЋИ ПЕРИОД: ПОРАЗ ГРУПЕ „28 БОљШЕВИКА” (1931-1935)}

У овом периоду изузетно су важна два датума: јануар 1931, за успон „28 бољшевика", и јануар 1935, за пад „бољшевика" и успон Мао Цедунга. У овом периоду постојале су две главне фракције: с једне стране „28 бољшевика", коју је водио Ванг Минг, а на другој Мао Цедунг и његове присталице. Обе групе могле би се поистоветити са одређеним националним интересима: „28 бољшевика” са совјетским интересима, Мао са кинеским интересима.

Најважнија карактеристика ове групе била је да су се сви вратили са школовања из Москве, имали су између 23 и 29 година, а били су снажни

Чен Дуксиу (Chen Duxiu, 1879-1942), кинески револуционарни социјалиста, филозоф и писац, у 1921. саоснивач кинеске Комунистичке партије, заједно са Лиом Дажаом, први генерални секретар КП Кине од 1921. до 1927. Био је водећа личност Ксинхај револуције, којом је збачена династија Чинг, и Покрета 4. мај за научни и демократски развој у раној Републици Кини. Избачен је 1929. из Комунистичке партије, а био је и лидер малог троцкистичког покрета у Кини. 
противници Троцког и истовремено присталице Стаљина. Њихов заштитник био је ректор Универзитета Сун Јатсен, Павел Миф, који их је практично довео на чело КП Кине и омогућио смењивање генералног секретара Ји Јианга. Име групе потиче из јуна 1929, када је неколико стотина студената Универзитета Суњат Сен учествовало на такозваној „Десетодневној конференцији” када је само 28 студената подржало линију Стаљина и Павела Мифа, како је навео Канг Шенг. Почела је „бољшевизација партије” и њено функционисање по совјетском моделу, стварање „совјета” у Кини.

У јесен 1934. Црвена армија више није била у стању да брани централни Совјет и напустила је Јиангки - ова операција касније се прославила као Дуги марш. Првобитно је марш требало да иде само до суседне провинције Хунан, а није планирано да буде дуг. Али како су Куоминтанг и војсковође блокирали планирану руту и напали комунисте, Црвена армија је кренула даље на запад, где је претрпела велике губитке - од 90.000 војника остало је само њих 30.000. Један од разлога за ове губитке био је покушај Кина Бангкиана, Чоуа Енлаја и Ота Брауна да крену према северу, где су јаке непријатељске трупе препречиле пут и напале Црвену армију. Због ових губитака и фрустрација војника и команданата, који нису разумели сврху операције, вођене су бројне дискусије које су се тицале будућности Комунистичке партије.

Зуниј конференција одржана је између 15-17. марта 1934. и одиграла је важну улогу. У кинеској и западној историографији често је карактерисана као најважнија конференција, или једна од најважнијих конференција, у историји Комунистичке партије Кине. Бивши уредник "Chinese Quarterly" Дик Вилсон, који је објавио једну од првих књига о "Дугом маршу”, дошао је до следећег закључка: „Ово је био најважнији састанак Политбироа у читавој историји странке, јер је драматично преокренула партијску политику и прекомпоновала своје вођство у корист Мао Цедунга, човека који је и након тога остао њена доминантна личност" (Wilson, 1972, p. 301).

Однос снага се преокренуо у корист Маоа, а главни разлог за то био је катастрофалан почетак Дугог марша. Тада је и Чоу Енлај променио страну и подржао Маоа. Пре и после конференције Чу Де је био председник Војне комисије. Чоу Енлај је остао политички комесар. Био је разбијен такозвани „тријумвират” Кина Бангкиана, Чоуа Енлаја и Ота Брауна, који је деловао као незванично руководство.

За разлику од Лењина и Троцког који су на руску револуцију гледали као на окидач за светску револуцију, Маови погледи су увек били „синоцентрични". 
Маова вера у крајњи успех перманентне револуције имала је упориште у идеологији, традицији и у кинеском национализму. Једно од најважнијих свакако је била и вера у отпорност, снагу и кохезију кинеског народа.

У једном есеју 1919. године он је истакао јединственост кинеског народа:

„Усуђујем се да направим јединствену тврдњу: једног дана, реформа кинеског народа ће бити дубља од било ког другог народа, а друштво кинеског народа ће бити сјајније од било ког другог народа. Велико јединство кинеског народа ће се остварити много раније него на другим местима или код других народа" (Schram, 1989, p. 23).

Следбеник троцкистичке струје у кинеском комунистичком покрету постао је њен први председник Чен Дуксију. Он се у августу 1937. срео са руководиоцима Комунистичке партије у Нанкингу, што је довело до заједничког покушаја Луоа Хана и Јиа Јиањинга да га врате у партију. Мао је одговорио у септембру рекавши да Чен може поново да се прикључи партији ако се сложи да се јавно одрекне троцкизма и подржи Уједињени фронт против Јапана. Чен је одговорио писмом ЦК КП Кине, где се сагласио с правцем отпора, али није напустио троцкизам. Био је то последњи озбиљан покушај да се врати у партију (Benton, 2017, p. 97-98).

Идејне борбе које су почеле од тренутка стварања Комунистичке партије Кине окончане су померањем равнотеже у корист идеја и ставова Мао Цедунга, чиме су створени услови за нову фазу развоја у деловању КП Кине.

\section{ЛИТЕРАТУРА}

1. Авдонин, А. Н. (1995). „В жерновах революции”, Банк культурной информ. Екатеринбург.

2. Benton, G. (2017). "Prophets unarmed: Chinese Trotskyists in revolution, war, jail, and the return from limbo". Haymarket Books.

3. Bland, J. O. P. (2015). Li Hung-chang, Newark: Palala Press.

4. Brandt, C. (1958). Stalin's Failure in China: 1924-1927. Cambridge, Massachusetts: Harvard University Press.

5. Дамье, В. В., Лиманов, К. А, (2020), Уижэнфуижуи. Истиория анархизма в Китиае, Москва: Ленан. 
6. Fenby, J. (2008). The Penguin History of Modern China: The Fall and Rise of a Great Power, 1850-2008, NY.

7. Хэнъюй, Г. Титаренко, М. Л. (1994). АО „Буклет”, Москва, Письмо Г.Н. Войтинского в Секцию восточных народов при Сиббюро ЦК РКП(б) // ВКП(б). В: Коминиеерн и национально-революиионное явижение в Кишиае. T. 1. стр. 30; Из доклада Исполкому Коминтерна об организации Секции восточных народов при Сиббюро ЦК РКП(б) //.

8. Jacobs, D. N. (1981). Borodin: Stalin's Man in China. Cambridge, Massachusetts: Harvard University Press.

9. Ян. Г. (2018). Роль совейскойо союза в ироииивосииоянии коммунистиической

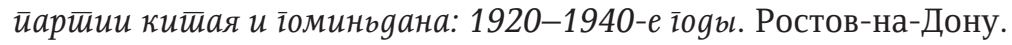

10. Кисинџер, Х. (2020). О Кини, Београд: Клуб ПЛУС.

11. Клик В. Н., Н. Г. (1981). Буримман-революиионер-иниернационалисти, Опыт и уроки истории КПК (К 60-летию образования партии)": Тез. докл. научн. конф. 7-8 апреля 1981 г. Москва.

12. Орешчанин, С., Павловић, П. (1960). Кина. Београд: Култура.

13. Сотникова, И. (2011). Коминеиерн и начало коммунисиической рабойы в

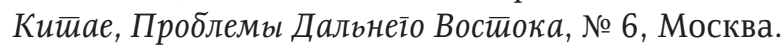

14. Snow, E. P. (1937). Red star over China. London.

15. Stuart, S. (1989). The Thought of Mao Tse-Tung. Cambridge: Cambridge University Press.

16. Taylor, J. (2009). The Generalissimo. Cambridge, MA: Harvard University Press.

17. Terrill, R. (1980). Mao. NY: Harper \& Row Publishers.

18. Усов, В. Н, (2002). Совейская развеgка в Кийае. 20-е їоgы ХХ века. Москва: ОЛМА Медиа Групп.

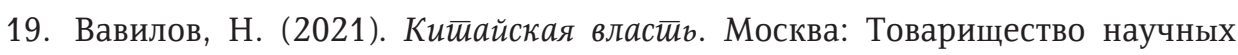
изданий КМК.

20. Van den Ven, H. J. (1991). From firend to comrade: The founding of Chinese Communist Party, 1920-1927. Los Angeles: Berkley, Oxford.

21. Wilbur, C. M. (1983). The Nationalist Revolution in China, 1923-1928. Cambridge: Cambridge University Press.

22. Wilson, D. (1972). The Long March: The Epic of Chinese Communism's Survival. NY: Viking Press. 


\title{
Dragan Bisenić
}

\section{IDEOLOGICAL STRUGGLES IN EARLY REVOLUTIONARY CHINA AND SOVIET INFLUENCE ON THE BOLSHEVISM OF THE CHINESE COMMUNIST PARTY}

\begin{abstract}
The communist ideology in China hovered and balanced between nationalism and internationalism, the proletariat and peasantry, urbanisation and underdeveloped rural areas and masses. It is in these extremes that leading personalities were brought up, and, depending on their origin, social status and contact with other parts of the world, formed their view of the proletarian revolution in China and its prospects.

Three periods can be distinguished in the development of the communist ideology in China prior to 1935 , later followed by a change in the power relations in favour of Mao Zedong who became the leader of the Chinese communists. The first period started with the first emergence of the communist parties in China, which were formed with the help of the Comintern instructors, and lasted until they established cooperation with the Kuomintang. The second period started with the split with the Kuomintang in 1927 and lasted until the election of so-called "Bolshevik leadership" in 1931. The third period refers to the "Bolshevik-Soviet" period of the Communist Party of China, which lasted from 1931 until 1935 and the Zunyi conference. They broke with that period, and the period of rise and dominance of Mao Zedong followed.
\end{abstract}

Keywords:

struggle of ideologies, Trotskyism, Mao Zedong, K. A. Stojanović. 